\title{
DYNAMICS OF TEMPERATURE CHANGES IN THERMOPHILLE PHASE OF COMPOSTING PROCESS IN THE ASPECT OF SANITARY CONDITION OF OBTAINED MATERIAL
}

\author{
Tomasz Jakubowski ${ }^{a^{*}}$, Piotr Sołowiej ${ }^{\mathrm{b}}$ \\ ${ }^{a}$ Institute of Machinery Management, Ergonomics and Production Processes, \\ University of Agriculture in Krakow \\ ${ }^{\mathrm{b}}$ Department of Electrotechnology, Power Industry and Automation, \\ University of Warmia and Mazury in Olsztyn \\ *Corresponding author: e-mail: tomasz.jakubowski@ur.krakow.pl
}

\begin{tabular}{|c|c|}
\hline ARTICLE INFO & ABSTRACT \\
\hline $\begin{array}{l}\text { Article history: } \\
\text { Received: September } 2016 \\
\text { Received in the revised form: } \\
\text { October } 2016 \\
\text { Accepted: November } 2016\end{array}$ & \multirow{2}{*}{$\begin{array}{l}\text { A condition of obtaining compost with proper sanitary parameters is } \\
\text { achieving the organic recycling process temperature which exceeds } \\
70^{\circ} \mathrm{C} \text {. The objective of the paper was to determine the temperature } \\
\text { course in the compost tank for organic recycling of dead poultry in } \\
\text { relation to the applied structure forming material. Wheat, oat, barley, } \\
\text { rapeseed and corn straw were used as a structure-forming material. } \\
\text { A measuring system was equipped with a probe with a temperature } \\
\text { sensor with precision of } \pm 0.15^{\circ} \mathrm{C} \text {, transducer and data recorder. } \\
\text { Results were prepared with the use of the analysis of variance at the } \\
\text { level of significance of } \alpha=0.05 \text {. Statistically significant differences of } \\
\text { the temperature value in the thermophille phase of the composting } \\
\text { process between combinations of the experiment were indicated. In all } \\
\text { investigated combinations of the experiment, achievement (or } \\
\text { exceeding) the temperature value of } 70^{\circ} \mathrm{C} \text { of the compost mass was } \\
\text { reported. }\end{array}$} \\
\hline $\begin{array}{l}\text { Key words: } \\
\text { composting, } \\
\text { poultry, } \\
\text { temperature, } \\
\text { hygienization }\end{array}$ & \\
\hline
\end{tabular}

\section{Introduction}

Poultry producers have to be aware of loses in poultry as a result of their death. The index of poultry deaths which includes weight of dead poultry and livestock of a farm according to various authors (Elson, 2015, Nicol et al., 2013, Rodenburg et al., 2013) is within 0.1 to $0.25 \%$ per a day and depends mainly on the assumed breeding system, poultry species (variety), designation and general welfare. It should be emphasised that in case of avian influenza, this index may assume higher values (Skorupski, 2011). Even in case of a very low index of death (approx. $0.1 \%$ ) poultry farms with numerous livestock face a problem of rational management of dead poultry (Brand-Klibanski et al., 2014). The most comfortable and the safest method on account of sanitary conditions is utilization of dead poultry in the form of combustion or as a feed for carnivorous animals. In case of the first method of utilization, a side effect is a fetor of fired carrion and the problem of ash utilization which is of a low fertilization value. The second one requires poultry with proper 
weight (amount of soft tissue) and without decay processes. However, chicks constitute a considerable interest of deaths and limiting decay processes requires the use of a refrigerator which is related to financial inputs and later transport of waste (Smoron, 2008, Spychaj-Fabisiak, 2007). An alternative method of utilization of the dead poultry is its limited recycling (Kopeć et al., 2014). The process of processing of poultry industry waste requires appropriate installation infrastructure, energy expenditures and plant raw materials resources (Romaniuk et al., 2009, Sapek, 2007, Staroń et al., 2010). Limited recycle for its correct course requires, firstly, relevant moisture (40-50\%) fragmented composted mass, compaction below $500 \mathrm{~kg} \mathrm{~m}^{-3}$, relevant relation of carbon to nitrogen (C:N as 25:1) and the presence of oxygen (above 5\%,13-21\% is recommended). An optimal system of these values influences activity of microorganisms in the compost mass, mainly mezophilic, thermophilic bacteria, actinomycetes and fungi. Development of thermophilic bacteria colonies causes the increase of the temperature of compost mass which results in, inter alia, in deactivation of pathogens. According to Golueke (1992) the composting process usually includes four basic stages: a low-temperature (mezophile) stage which includes ahydrolysis process and oxidization of organic substance; a hightemperature (thermophile) stage where organic substance decays fast, a period of temperature drop, when the composted mass volume is decreased and the stage of cooling the compost (psychrophile phase) and formation of stable humus related thereto. The activity of microorganisms causes the increase of temperature of the compost prism to approx. $60^{\circ} \mathrm{C}$ (Pilarski et al., 2009) and according to some authors (Dach, 2010) even to $74-77^{\circ} \mathrm{C}$. Such thermal conditions lead to natural sterilization (deactivation of pathogens) of the composted mass. The Polish law (Act ...2007, Resolution ...2008) provides that organic fertilizers and substances which support plant cultivation meet the sanitary and hygienic criteria. Living bowel parasites (Ascaris sp., Trichuris sp., Toxocara sp.) and Salmonellabacteria cannot occur in composts and ferments. The European Union law (Resolution...2009, Rynkiewicz, 2005) requires that temperature in the composting process (in the thermophile phase) should achieve the value of $70^{\circ} \mathrm{C}$ which guarantees appropriate hygienization of organic substance and enables management of the compost for fertilization purposes.

The objective of the paper was to determine the temperature course (in the aspect of hygienization) in the compost tank for organic recycle of dead poultry in relation to the use of structure forming material.

\section{Research method}

The research was carried out in Spring 2015 in an enterprise dealing with animal and plant production. Material for the experiment came from a poultry farm which breeds chickens (Gallus gallus domesticus) bred for meat and eggs (general utility species mainly Messa, and Playmouth rock). The farm had production buildings, administrative and social premises and storages: of fodder, litter, equipment and eggs. The production premises included: nursery, growing house and henhouses. Production premises met requirements set forth for this facility with regard to their insulating properties, ventilation, insulation from the ground and their equipment and surface are adjusted to the type and intensity of production. Poultry production was carried out in the floor and litter system and the 
Dynamics of temperature changes...

livestock was 3500 chickens. Compost boxes with dimensions of 1.4/1.0/1.0 m equipped with a perforated bottom were used in the experiment. Compost boxes dimensions were justified with the need of manual shifting of the mass and perforation of the bottom enables aeration of the mixture. Both the process of aeration and mixing of the compost mass were carried out according to the methodology predicted for organic recycle (Bień et al., 2011, Dach, 2008, Gałwa-Widera, 2014, Sołowiej et al., 2010, Wieland, 2008,). The temperature inside the material was determined with the measurement step of 60 minutes. A certified measuring system (Dekra, ISO 9001:2008) was equipped with the probe (AC1904), sensor (P100 class A scope: $-70+110^{\circ} \mathrm{C}$ ) with the precision $\pm 0.15^{\circ} \mathrm{C}$, transducer (ThermoFlex5) and data recorder (MPI-8, 4-20 mA). In the composting process, as a structure forming material five types of dried straw were used: wheat, oat, barley, rapeseed and maize (respectively combinations no: 1, 2, 3, 4 and 5). Selection of the straw type depends on the straw availability on the farm. The batch to the compost box included; litter (straw with droppings), straw and dead poultry in the volumetric proportions 2:1:1. Such proportion (Kopeć et al., 2014) ensures appropriate relation of carbon to nitrogen (C:N as 25:1). The composting process was carried out for 45 days to the moment stable compost was obtained. Two first stages of the composting process were included for realization of the assumed objective (mezo- and thermophile phase). Such choice is justified with the fact that hydrolysis and oxidization processes of organic substance take place in the lowtemperature phase with participation of mezophile bacteria. These changes are accompanied by the increase of the compost mass temperature to approx. $40-45^{\circ} \mathrm{C}$ and then the process changes into a high-temperatures phase where with participation of thermophile bacteria decomposition of fats, proteins, cellulose, hemicellulose and other complex hydrocarbons takes place. The thermophile phase is accompanied by the increase of the temperature to approx. $60-70^{\circ} \mathrm{C}$. For the needs of unification of the experiment, temperature was measured to the moment the temperature in compost boxes in the final stage of thermophile phase obtained the value below of $50^{\circ} \mathrm{C}$ and did not raise in the subsequent 3 days by more than $5^{\circ} \mathrm{C}$. The obtained results were analysed at the level of significance of $\alpha=0.05$ with the use of STATISTICA 12 . The analysis of variance preceded by the research on the regularity of the distribution in samples (Kolmogorov-Smirnov test) and the uniformity of variance (Levene's test) was carried out. Differences between the statistically significant averages were investigated with Tukey's test of multiple comparisons. Groups of homogeneous variables were determined. Graphical presentations of the temperature course in the investigated compost process were formed based on the average values from daily measurements but values exceeding $40^{\circ} \mathrm{C}$ for the mezophile phase and $50^{\circ} \mathrm{C}$ for thermophile phase were included. Such included temperature scope allowed estimation of the beginning and end of the thermophile phase.

\section{Research results and discussion}

Results of Kolmogorv-Smirnov's and Levene's tests allowed a parametric analysis of variance of the investigated variables and determination of the value of $F$ Snedector's statistics. Statistically significant differences were reported in relation to the applied structure-forming material as to the value of the measured temperature in the thermophile phase of the composting process (Table 1). The obtained results indicate that in all 
combinations of the experiment the compost obtained temperature above $70^{\circ} \mathrm{C}$. However, dynamics of achieving the maximum temperature (exceeding $70^{\circ} \mathrm{C}$ ) by particular combinations was different. The highest temperature $\left(74.1^{\circ} \mathrm{C}\right)$, and achieved in the shortest time was reported in case of maize straw (Fig. 1). Such result of experiment was compliant with the research presented by Dach (2010) where he determined the course of the composting process of sludge (with participation of maize straw) and the size and dynamics of ammonia emission. In the literature (Kopeć et al., 2014) we may also find information according to which in the process of composting of slaughter waste (mainly fat, ceratin, feather and droppings) at the participation of maize straw, the temperature of the process exceeded the value of $60^{\circ} \mathrm{C}$. In case of the use of rapeseed straw the maximum temperature which was reported was $70.4^{\circ} \mathrm{C}$. Combinations, where structure-forming material was used in the form of wheat straw had similar values of maximum temperatures where the values were around $72^{\circ} \mathrm{C}$ (combinations which include barley straw achieved the maximum value the latest). In the sanitation process it is significant that the composted mass temperature is $70^{\circ} \mathrm{C}$ and this value is maintained by the determined time. Graphical analysis (Fig. 1) indicates that in combinations including maize and wheat straw the temperature of $70^{\circ} \mathrm{C}$ was maintained by approx. 3 days. On account of the specificity and expected lack of equipotency in tests in the final stage of experiment the Spjotvoll and Stoline's procedure was used as a test for multiple comparisons (generalization of HSD Tukey's test). Three homogeneous groups were obtained (Table 2).

Table 1.

Results of one-way analysis of variance - impact of used structure-forming material on the course of temperature of the composting process

\begin{tabular}{|c|c|c|c|c|c|}
\hline \multirow[b]{2}{*}{$\begin{array}{l}\text { Independent } \\
\text { variable }\end{array}$} & \multirow[b]{2}{*}{$\begin{array}{l}\text { Sum of } \\
\text { squares }\end{array}$} & \multirow[b]{2}{*}{$\begin{array}{l}\text { Degrees of } \\
\text { freedom }\end{array}$} & \multirow[b]{2}{*}{$\begin{array}{l}\text { Average } \\
\text { square }\end{array}$} & \multicolumn{2}{|c|}{ Value of } \\
\hline & & & & $\begin{array}{c}\text { F Snedecor's } \\
\text { test }\end{array}$ & $\begin{array}{c}\text { of test } \\
\text { probability }\end{array}$ \\
\hline Absolute term & 1598687 & 1 & 1598687 & 16055.89 & 0.0000 \\
\hline Structure-forming material & 1375 & 4 & 344 & 3.45 & 0.0085 \\
\hline Error & 50681 & 509 & 100 & & \\
\hline
\end{tabular}

Table 2.

Results of Spjotvoll's and Stolinea's test (homogeneous groups system) -impact of used structure-forming material on the course of temperature of the composting process

\begin{tabular}{lll}
\hline Group no. & Structure-forming material & Temperature $\left({ }^{\circ} \mathrm{C}\right)$ \\
\hline 1 & maize straw & 59.1 \\
2 & wheat straw, oat straw, barley straw & $55.4-56.1$ \\
3 & rapeseed straw & 54.2 \\
\hline
\end{tabular}




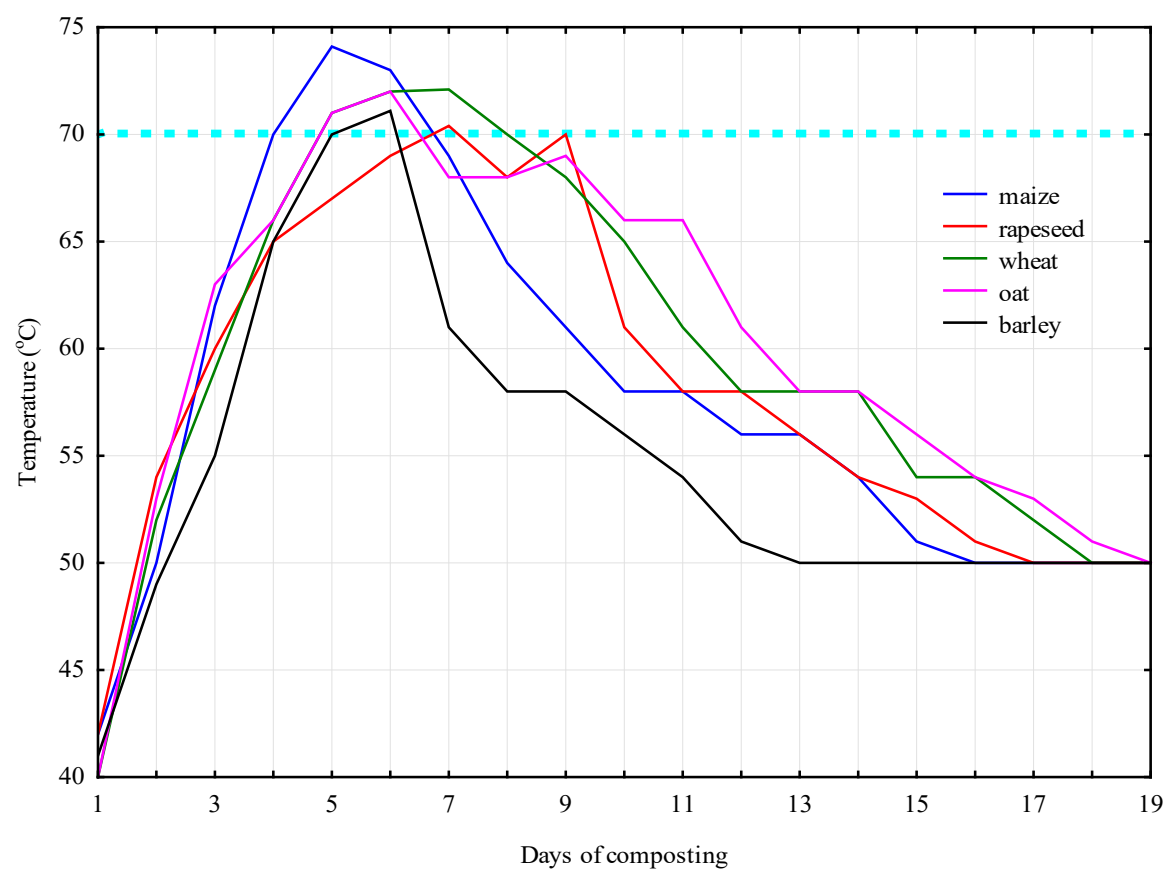

Figure 1. Change of temperature during the composting process (dotted line marks reference to the value $70^{\circ} \mathrm{C}$ )

\section{Conclusions}

1. The applied combinations of the structure forming material significantly influence the course of the composting process temperature.

2. All investigated combinations of the experiment achieved (or exceeded) the temperature value of $70^{\circ} \mathrm{C}$ in the composting mass.

\section{References}

Bień, J., Milczarek, M., Neczaj, E., Worwąg, M., Okwiet, T., Kowalczyk, M. (2011). Composting process as an alternative method for the disposal of sewage sludge and organic fraction of municipal solid waste. Civil and Environmental Engineering Reports, 6, 127-136.

Brand-Klibanski, S., Yalin, D,, Shenker, M. (2014). Comment on "Formations of Hydroxyapatite and Inositol Hexakisphosphate in Poultry Litter during the Composting Period: Sequential Fractionation, P K-edge XANES and Solution 31P NMR Investigations. Environmental Science Technology, 48(16), 9955-9956.

Dach, J. (2008). Kompostowanie trawy i liści. Przegląd Komunalny, 10, 36-40.

Dach, J. (2010). Influence of different straw kind additive on the process dynamics and size of ammonia emission from composted sewage sludge. Journal of Research and Applications in Agricultural Engineering, 55(2), 1-13. 
Elson, H.A. (2015). Select Poultry welfare in intensive and extensive production systems. World's Poultry Science Journal, 71(3), 449-460.

Gałwa-Widera, M. (2014). Unieszkodliwianie osadów ściekowych w procesie kompostowania z zastosowaniem różnych cykli napowietrzania. Inżynieria $i$ Ochrona Środowiska, 17(4), 661-671.

Golueke, C. G. (1992). Bacteriology of composting. Bio Cycle, 33, 55-57.

Kopeć, M., Gondek, K., Orłowska, K., Kulpa, Z. (2014). Wykorzystanie odpadów z ubojni drobiu do produkcji kompostu. Inżynieria Ekologiczna, 37, 143-150.

Nicol, C.J., Bestman, M., Gilani, A-M., $\quad$ De Haas, E.N., $\quad$ De Jong, I.C., Lambton, S., Wagenaar, J.P., Weeks, C.A., Rodenburg, T. B. (2013). The prevention and control of feather pecking: application to commercial systems. World's Poultry Science Journal, 69, 775-788.

Pilarski, K., Pilarska, A. (2009). Parametry procesu kompostowania. Technika Rolnicza Ogrodnicza i Leśna, 1, 1-2.

Rodenburg, T.B. (2013). The prevention and control of feather pecking: application to commercial systems. World's Poultry Science Association, 69, 775-787.

Rodenburg, T.B., Van Krimpen, M.M., De Jong, I.C., De Haas, E.N., Kops, M.S., Riedstra, B.J., Nordquist, R.E., Wagenaar, J.P., Bestman, M., Nicol, C.J. (2013). The prevention and control of feather pecking in laying hens: identifying the underlying principles. World's Poultry Science Journal, 69, 361-373.

Romaniuk, W., Domasiewicz, T., Karbowy, A., Wardel, W.J. (2009). Ograniczenie wpływu produkcji zwierzęcej na środowisko. Inżynieria Rolnicza, 1(110), 233-242.

Rozporządzenie Ministra Rolnictwa i Rozwoju Wsi z dnia 18 czerwca 2008 r. w sprawie wykonania niektórych przepisów ustawy o nawozach i nawożeniu, Dz. U. Nr 119, poz. 765

Rozporządzenie (WE) № 1069/2009 Parlamentu Europejskiego i Rady z dnia z dnia 21 października 2009 określające przepisy sanitarne dotyczące produktów ubocznych pochodzenia zwierzęcego, nieprzeznaczonych do spożycia przez ludzi, i uchylające rozporządzenie (WE) nr 1774/2002 (rozporządzenie o produktach ubocznych pochodzenia zwierzęcego).

Rynkiewicz, A. (2005). Polskie regulacje prawne w zakresie ochrony środowiska przed zanieczyszczeniami pochodzenia rolniczego w świetle integracji z Unią Europejską. Rolnictwo Polskie i ochrona jakości wody. Zeszyty Edukacyjne IMUZ, 10, 57-69.

Sapek, A., Sapek, B. (2007). Zmiany jakości wody i gleby w zagrodzie i jej otoczeniu w zależności od sposobu składowania nawozów naturalnych. Zeszyty Edukacyjne IMUZ, 11, 10-108.

Skorupski, J. (2011). Wielkoprzemysłowe fermy drobiu i trzody chlewnej w Polsce. Federacja Zielonych „GAJA”. Szczecin. ISBN 978-83-924-762-6-9.

Smoroń, S. (1998). Przenikanie substancji biogennych ze źródeł rolniczych do środowiska - czynnik eutrofizacji wód powierzchniowych. Zeszyty Edukacyjne IMUZ, 5, 57-70.

Sołowiej, P., Piechocki, J., Neugebauer, M. (2010). Wpływ napowietrzania złoża na przebieg pierwszej fazy procesu kompostowania. Inżynieria Rolnicza, 3(121), 193-198.

Staroń, P., Banach, M., Kowalski, Z., Wzorek, Z. (2010). Unieszkodliwianie wybranych odpadów poubojowych na drodze hydrolizy. Chemia, 1, 333-341.

Spychaj-Fabisiak, E., Kozera, W., Majcherczak, E., Ralcewicz, M., Knapowski, T. (2007). Oddziaływanie odpadów organicznych i obornika na żyzność gleby lekkiej. Acta Scientiarum Polonorum Agricultura, 6, 69-76.

Ustawa z dnia 10 lipca 2007 roku o nawozach i nawożeniu, Dz. U. nr 147, poz. 1033.

Wieland, E. (2008). Wytwarzanie kompostu i humusu. Przegląd Komunalny, 4, 40-44. 


\title{
DYNAMIKA ZMIAN TEMPERATURY FAZY TERMOFILNEJ PROCESU KOMPOSTOWANIA W ASPEKCIE STANU SANITARNEGO UZYSKANEGO MATERIALU
}

\begin{abstract}
Streszczenie. Warunkiem uzyskania kompostu o odpowiednich parametrach sanitarnych jest osiągnięcie $\mathrm{w}$ trakcie procesu recyklingu organicznego temperatury przekraczającej $70^{\circ} \mathrm{C}$. Celem pracy było określenie przebiegu temperatury w skrzyni kompostowej przeznaczonej do organicznego recyklingu padłego drobiu $\mathrm{w}$ zależności od zastosowanego materiału strukturotwórczego. Jako materiał strukturotwórczy zastosowano słomę pszeniczną, jęczmienną, owsianą, rzepakową $\mathrm{i}$ kukurydzianą. $\mathrm{W}$ badaniach korzystano $\mathrm{z}$ układu pomiarowego wyposażonego w sondę z czujnikiem temperatury o dokładności $\pm 0,15^{\circ} \mathrm{C}$, przetwornik i rejestrator danych. Wyniki opracowano $\mathrm{z}$ wykorzystaniem analizy wariancji na poziomie istotności $\alpha=0,05$. Wykazano statystycznie istotne różnice wartości temperatury $\mathrm{w}$ fazie termofilnej procesu kompostowania między kombinacjami doświadczenia. We wszystkich badanych kombinacjach doświadczenia stwierdzono osiągnięcie (lub przekroczenie) wartości temperatury $70^{\circ} \mathrm{C}$ masy kompostowej.
\end{abstract}

Słowa kluczowe: kompostowanie, drób, temperatura, higienizacja 